\title{
Southern African Governments, Multilateral Development Banks, Non-State Actors, and Sustainable Infrastructure: Managing Changing Relationships
}

\author{
Daniel D. Bradlow* \\ University of Pretoria
}

\begin{abstract}
There is a need for the countries of Southern Africa to invest in building infrastructure, for which purpose they can be expected to utilise the services of multilateral development banks (MDBs). MDB-funded infrastructure projects often become arenas for debate over the roles of different actors in the development process. This article discusses the fact that there is no longer a clear consensus on the relative responsibilities of governments, MDBs and non-state actors in regard to infrastructure projects, and analyses how these new tensions in the relations between these three actors could complicate efforts to develop the infrastructure so urgently needed in Southern Africa.
\end{abstract}

Key Words: Southern Africa; infrastructure projects; multilateral development banks; social and environmental impacts; non-state actors

There is an urgent need for the countries of Southern Africa to invest in building infrastructure. ${ }^{1}$ This investment is needed both to provide the citizens of the region with more and better access to power, transport, water and telecommunications services and to help create the economic opportunities that will allow all the inhabitants of the region to lead lives of dignity and opportunity.

While not inevitable, it is likely that Southern African governments will rely on large infrastructure projects to meet these needs. The reason is that most governments perceive large projects to be the most effective way to help as many people as possible to gain access to the desired services as quickly as possible. The challenge is that large projects tend to be controversial because they raise complex technical, economic, financial, political, environmental, and cultural issues about which their citizens are likely to have conflicting views. In resolving these issues, the governments that sponsor the projects will need to make

*danny.bradlow@up.ac.za 
difficult choices that can have profound and unintended positive and negative short and long term consequences for the various stakeholders in the project.

Given the region's infrastructure needs, and the likely costs and the technical complexities of the infrastructure projects that will be utilised to meet these needs, it is unlikely that Southern African countries will be able to fully satisfy their individual and collective needs from their own resources. Consequently, they can be expected to utilise the services of external providers of financial and technical services in planning and constructing these infrastructure projects. One of the key sources of such services for developing countries like those of Southern African is the multilateral development banks (MDBs), such as the World Bank Group and the African Development Bank. ${ }^{2}$ These MDBs can offer their member states three benefits. First they can offer them financing on terms (interest rates, loan duration, grace periods) that are usually better than those the project sponsors can obtain from commercial sources. Second, MDB participation can help encourage other public and private financial institutions to participate in the financing of a project on better terms than might otherwise have been the case. Third, the MDBs have had considerable experience supporting infrastructure projects in developing countries. Consequently, they can offer their borrowers the benefits of the lessons they have learned from working on similar projects in other countries. $^{3}$

These MDB benefits, however, do not come without at least three substantial complications. The first complication arises from the fact the MDBs are international organisations. This means that they are subjects of international law and are expected to comply with all applicable principles of customary and treaty based law. This means that they must pay due regard, inter alia, to the international community's evolving views of how human rights and environmental laws should apply to investment projects like infrastructure projects. While the application of these legal principles to development projects usually leads to improvements in the projects in social and environmental terms, this makes the planning, construction and operation of the projects more complex, slower and more controversial. The second complication arises from the fact that the MDBs' biggest and most influential member states can use their voice, vote and financial contributions to influence MDB operational policies and practices. ${ }^{4}$ Unsurprisingly, these members use this influence to advance their own interests and the concerns of their citizens rather than those of the member states that actually use the services of the MDB. In this regard, it is important to note that the financial contributions that member states make to the MDBs are ultimately contributed by the 
taxpayers of those states. As a result, the MDBs need to take the concerns of these taxpayers, at least as expressed through their governments, into account in the design and implementation of their operational policies and practices. The third complication arises from the fact that the MDBs are relatively more transparent and accountable than purely private financial institutions..$^{5}$ As a result, it is easier for interested observers to learn about and understand how they relate to their member states and to other stakeholders in the projects they fund and how they manage any controversies associated with those projects. While this may ultimately result in better projects, again it can slow down and complicate the planning and implementation of MDB-funded projects.

The net effect of these complications is that MDB-funded infrastructure projects often become one of the arenas in which debates about the role of different actors in the development process are played out most concretely, given that the debates are framed around specific projects. Consequently, the operations of MDBs are useful vehicles for studying how views on the best ways to design, construct and operate infrastructure projects are changing in light of experience and our growing understanding of the development process. They also can offer us insights into the way in which the relationships between the state, international organisations like the MDBs and non-state actors, such as corporations and non-governmental organisations, are evolving in response to these developments.

The purpose of this paper is to explore how views of best practices in planning and constructing infrastructure projects are evolving and the implications of these changes for relations between the Southern African states, the MDBs and non-state actors. It is divided into three sections. The first section will describe how our understanding of development, particularly in regard to best practices for designing and constructing infrastructure projects, has evolved. The second section will explore implications, and particularly the tensions that are generated within the relationships between these three groups of actors by this evolution in our understanding of development. The final section will discuss the implications of these issues for South Africa and Southern Africa in respect to its relationship with the MDBs.

\section{An evolving understanding of responsible infrastructure project planning}

The triangular relationship between the state, the MDBs and non-state actors in MDBsupported projects has never been purely economic in nature. It has always involved the inevitable political considerations that arise in any transaction between a sovereign state and an international organisation. These relationships, however, have become even more 
complex over time. There are at least two reasons for this evolution. The first is that the international community has become more concerned about the environment and about human rights. In the context of infrastructure projects, this has translated into a concern about how the social and environmental impacts of projects are accounted for in the planning, construction and operation of the project. The second, which is a consequence of the first, is that the role of the MDBs in the development project financing process is changing. It is no longer sufficient for any MDB to see itself merely as a funder of development, whose primary responsibilities, prior to making any lending decision, are to evaluate the technical and economic feasibility of the project and the borrower's ability to repay its debts. It must now also see itself as having a responsibility to ensure that the projects it funds are environmentally and socially sustainable. ${ }^{6}$

This expansion in the role and responsibilities of the MDBs has complicated their engagements with their member states and with non-state stakeholders in the projects. It has also generated a great deal of controversy. At one time there was a general consensus on what the rights and obligations of the state, the MDBs and the affected non-state actors in regard to MDB operations were. However, under the weight of the expanding role of the MDBs this consensus has broken down. Unfortunately, while there is an emerging view on how these parties should relate to each other, there is not yet a new general consensus on how these actors should arrange and manage their relationships with each other. The result is that the triangular relations between the MDB, the sponsoring state and the affected non-state actors are generating more conflict than before. In order to understand the parameters of this conflict and its implications for this triangular relationship, it is necessary to understand both how the 'old consensus' view saw these relationships and how they are seen in the context of the emerging view.

\section{The old consensus view}

The starting point in the old consensus is that development should be seen as an economic process focused on generating growth in each society. The function of development practitioners, such as the MDBs and the government officials who utilised their services, was to promote technically and financially feasible infrastructure projects that would support the growth of the economy of that country. They recognised that development projects, such as infrastructure projects, have social, environmental, and political implications but argued that these should be dealt with separately from the financial and technical aspects of the project. 
According to this consensus view, project decision-making should be divided into two parts. First, there are broad policy issues in which decisions are made through the political process by the government and society in which the policy or project will be implemented. Examples of broad policy issues include: (1) how much of the budget should be allocated for infrastructure projects and how this amount should be allocated among the various infrastructure needs of the country; (2) whether the transport system should be based on roads which will encourage private car ownership or on a public transport system, and, if the latter, which communities should be served by the system; and (3) should the country's energy system be based primarily on domestic coal, renewables or imported gas. In making these decisions, the broad policy decision-makers also implicitly or explicitly make decisions about what sorts of environmental and social costs they expect the society to absorb and about how the costs and benefits of these decisions will be allocated among different social groups, both in the present and over time. The second category consists of project-specific decisions. Examples of these types of decisions are: (1) the design of the project; (2) the most feasible construction method for the project; and (3) from which sources should the funds to finance the particular project be raised. The consensus view is that those responsible for these decisions should focus their attention only on these project specific issues and defer to the broad policy decision-makers on all other issues.

According to the consensus view, the responsibility for the first type of broad policy decisions belongs exclusively to the government and the society that it governs. This means, for example, that in a democracy, the society will elect a government and delegate to it the responsibility to decide, inter alia, what types of infrastructure needs will be prioritised this year, which specific projects will be undertaken during the year, and how to deal with the social and environmental costs arising from the project. If the electorate is not satisfied with the government's decisions in regard to these matters it can, in principle, vote the government out of office in the next election. ${ }^{7}$ The MDBs are expected to treat these issues as being the prerogative of the society or government in which the project is being built. This means that, from the MDBs' perspective, they can operate on the assumption that the society or government in which the project is located has decided how it wishes to manage its own environment and how it wants to share the various social, environmental, and economic costs and benefits of the project among the various stakeholders in these projects. Under this view, 
MDBs can treat these decisions as background facts during the project negotiations and when they make their own project-related decisions.

One consequence of this view is that it suggests that the first responsibility of the MDBs is to evaluate each project in terms of its technical, financial and economic feasibility. A project would be deemed worthy of financial support so long as all technical problems can be resolved at a reasonable cost, the project has a clear economic benefit, ${ }^{8}$ and the borrower can be expected to generate - either from the project or elsewhere - the cash needed to repay the debt. The MDB's remaining duties are to draft and negotiate appropriate loan agreements with the borrower and then to monitor their execution.

If non-state actors, such as communities that are interested in or affected by the project, wish to participate in the project's decision-making process, they would need to consult with the government because it has the responsibility to make decisions about the broad social, political, environmental, and cultural implications of the project. They would not need to consult with the MDB unless they have concerns about specific issues relating to the financing or technical aspects of the project.

Similarly, the range of people with which the MDB would need to consult before making any particular project decision is limited under the old consensus. Since it is responsible for technical and financial issues only, the MDB only needs to consult with experts on these issues before making its decisions. An MDB may also choose to consult with the government about the broad policy decisions that have shaped the context in which the project must be constructed and operated to better understand that context. However, in this view, non-expert non-state actors are unlikely to have information that is relevant to the technical and financial decisions that the MDB must make.

This view makes it easy to identify to whom the different participants in the project are accountable. Project funders like the MDBs are likely to be accountable to only two groups. First, they are responsible to their member states and their senior management for complying with their operational policies and procedures and the treaties that created them. Second, they are accountable to their borrowers for the performance of their contractual obligations. 
They are accountable to the project's intended beneficiaries and those adversely affected by the project in only two situations. The first is when they have a direct contractual relationship with these other stakeholders. The second is when they have engaged in activities that have resulted in harm to these other stakeholders and there is a forum that is willing to entertain the victim's claim. This forum could be a national court or an international body. However, in the case of MDBs, this is an unlikely occurrence because as funders they are not themselves undertaking the sorts of activities that can result in such claims. Moreover, even if they had engaged in such activity, the organisational immunity that all international organisations enjoy would protect them from being sued. ${ }^{9}$

The state, as the party with decision-making responsibility for the broader social and environmental aspects of the project, is accountable to the intended beneficiaries of the project and those adversely affected by the project. The general consensus assumes that, where appropriate, accountability is imposed on the state through the political system. In other words, the proponents of this view are relying on the two primary mechanisms of accountability in democratic governance to hold governments responsible for their decisions and actions relating to specific policies or projects. As indicated above, the first mechanism is the periodic elections for a new government. Thus, interested persons can vote against a government which has sponsored or approved a problematic project. This is not a particularly effective means of accountability in regard to the government's management of specific projects, however; it is unlikely that the electorate as a whole will base its decision on the government's conduct in one project that may only affect a portion, possibly a very small portion, of the electorate. The second mechanism is whatever administrative or judicial procedures the state might have established through which interested private actors can challenge governmental decisions.

It should be noted that the top-down nature of decision-making and the limited range of accountabilities described above both suggest that the traditional view contemplates a limited role for domestic non-governmental organisations (NGOs) in development. Unless these groups are project contractors, their role is limited to assisting project victims hold project decision-makers accountable for the harm caused by their decisions and actions in the project. Their efficacy in doing so will depend, in the first instance, on how much access they have to domestic judicial and administrative tribunals, international fora and the media. They may 
also be able to hold decision-makers accountable through developing international campaigns in conjunction with international NGOs. ${ }^{10}$

A third implication that follows from the traditional view is the constraints it places on the topics that are open for negotiation in the structuring and negotiating of the financial transactions associated with any infrastructure project. In this view, the broad social, political and environmental decisions relating to the project should be treated as fixed and outside the scope of the negotiations between the project sponsor and the MDB. This is consistent with the legal rule that a foreign entity entering into a transaction with a host state has an obligation to obey the law of the host state and to refrain from interfering in the domestic affairs of the host state. ${ }^{11}$

A fourth implication is that the consensus view of decision-making in regard to infrastructure projects is consistent with the principle of respect for state sovereignty. ${ }^{12}$ The consensus view, by treating social, political and environmental factors as outside the scope of their responsibilities, is implicitly defining the scope of the state's sovereignty in regard to the other stakeholders in the project. It is making clear that decisions relating to the social, political and environmental consequences of development should be taken by the sovereign and its decisions should be respected by the other actors in development.

It is important to recognise that this old consensus view still has adherents, particularly among people who are concerned with protecting the sovereignty of the state. Their point that the state has both the responsibility and the right to make broad policy decisions and to have these decisions respected is powerful and has a firm basis in international law and international relations. However, this consensus is being undermined by the mounting empirical evidence that in too many cases governments and project sponsors have underestimated project and policy costs and overestimated their benefits, with the result that they have mistakenly supported and constructed (and continue to construct) projects which cause considerable harm and are often financially, environmentally and socially unsustainable. ${ }^{13}$

This undermining is also, in part, a consequence of two other factors in human affairs. The first is our growing recognition of the limits on the ability of the environment to absorb the costs generated by human activity. This has led to increasing importance being attached to 
the project planning process. In particular, there is increased recognition of the importance of incorporating into the planning stage an assessment of all the environmental and social impacts associated with any particular human activity. The responsibility for assessing the impact of an activity typically resides with the party who is undertaking the activity in question. ${ }^{14}$ As a result, many project stakeholders are demanding that project sponsors, and those providing them with the financial and other services that the project requires, make sure that they can account for all the human and physical environmental costs and benefits of the proposed project before it is approved. This is a significant change from the consensus view which assigned this responsibility to the state sovereign and allowed all other actors to defer to the sovereign's decision in this regard.

The second development is the increasing influence of international human rights law and fora around the world. ${ }^{15}$ The development of international human rights law has educated governments and international organisations about their responsibilities towards those who are affected by their actions. It has also raised awareness among people about their rights and increased their willingness to take steps to oppose development projects that they believe will harm them. The existence of new international mechanisms for raising human rights claims means that it is now possible for many of those who are adversely affected by development projects to challenge these projects in an international forum where they can obtain an 'on the record' hearing. It is also becoming possible for the adversely affected people to seek to hold accountable the perpetrators of the actions that caused the harm and those who aided and abetted them. For example, people who feel that they have suffered material harm because an MDB has not followed its own operating rules and procedures can file a 'Request for Inspection' with the MDB's independent accountability mechanism. ${ }^{16}$ Similarly, groups who feel that development projects are violating their human rights may be able to file claims before such bodies as the African Commission on Human and People's Rights. ${ }^{17}$ In addition in some cases, domestic courts in the project sponsor's or contractor's home state have been willing to consider these cases. ${ }^{18}$ Regardless of the outcome of the proceedings in these fora, the mere fact that the cases have been filed can impose reputational and financial costs on the MDB and the government which approved the project. The increased costs can be sufficient to change the calculus of the project's costs and benefits. The result is that, in addition to public interest groups, some in the corporate sector are calling for all the key actors in the project to take more account of human rights considerations in their project planning. This has resulted in the development of standards against which the MDBs and private financial 
institutions should assess the projects they are considering funding. Examples include the IFC Sustainability Framework, ${ }^{19}$ the Equator Principles ${ }^{20}$ and the UN Guiding Principles on Business and Human Rights. ${ }^{21}$ The World Bank is currently in the process of formulating, after an extensive consultation process, a new set of standards for its operations as well. ${ }^{22}$

\section{The emerging view}

These developments have contributed to a new emerging view of development, set out in general terms in documents like the United Nations Declaration on the Right to

Development, ${ }^{23}$ which argues that the economic aspects of development cannot be separated from its social, political, environmental and cultural aspects and that, as a result, development should be seen as one economically, politically, socially, culturally and environmentally integrated process. From this perspective, infrastructure projects should be treated not so much as discrete economic events but as episodes of social, economic and environmental transformation that are part of an ongoing process of change. This means that to fully assess the desirability of a particular project, it is necessary to account for all the ways the project is likely to affect the social and physical environment in which it is to be located and how these impacts will evolve over the life cycle of the project. Without all this information the decision-makers cannot be confident that they understand the economic, financial, environmental, social, cultural and political consequences of their decisions. They also cannot accurately assess all the costs and benefits of any proposed project, thereby increasing the risk that they will approve projects which will produce fewer benefits and more harm than anticipated.

There are a number of consequences that follow from this view. The first is that the MDBs have greater and more complex responsibilities than those assigned to them by proponents of the old consensus view. Under the emerging view they are seen as being responsible for both prudent financial decisions in regard to the projects that they fund and for comprehensive assessments of the impact of these projects on the physical and human environment in which they are situated. This means that it is no longer seen as acceptable for the MDBs to treat social and environmental factors as part of the broad policy issues that are the prerogative of the state and that are outside their scope of responsibility. They are now expected to account for them in their operational decision-making processes. ${ }^{24}$ In other words, it is no longer seen 
as prudent, in an economic or risk management sense, for the MDBs to rely exclusively on government decisions relating to environmental and social matters.

The second consequence is that proponents of this view attach great importance to consultations between project decision-makers and all those who will be affected by the proposed project. The reason is that the project decision-makers can only be confident that they have accurately assessed the costs and benefits of the project if they understand how those who will be affected by the project will react to the project and the resulting changes in their social and physical environment. This information can only be uncovered through consultation with all those parties who will be affected by the project or who have the ability to influence how these affected parties will respond to the project.

The emphasis on consultations has two important implications. The first is that the consultation process can only be productive and lead to better decision-making if the various stakeholders, including the affected people, are provided with adequate information about the project in a timely manner. Unless these people have sufficient information on the project to understand its potential impacts, they cannot know with any confidence how they will respond to the project. The need for consultation, therefore, necessarily leads to a requirement for disclosure of information, which has been formalised in the operational policies and procedures of the MDBs. ${ }^{25}$

The second implication is that the need for consultation can partially localise the focus of the project. Under the old consensus view of development, project sponsors and contractors only needed to consult the authorities responsible for sponsoring the project, usually national authorities, in the course of making project-related decisions. Now however, they must pay greater attention to local concerns and impacts, even if the project's ultimate rationale is to provide national or even transnational benefits. This necessarily has the effect of empowering local stakeholders and their representatives in their consultations with the MDB and the government. In this regard, it is important to note that the emerging view highlights the importance of consulting groups traditionally excluded from power, such as women and indigenous people. Since both these groups have the ability to influence the future impact of the project and its likely success, they cannot be ignored in the project consultation process. ${ }^{26}$ 
The above suggests that the emerging view requires a more participatory form of decisionmaking than the old consensus view of development. The reason is that without people knowing that they are able to influence the decision-making process, they are unlikely to have confidence in and be willing to take part in the consultation process. This in turn means that project decision-makers who insist on a top-down form of decision-making are unlikely to obtain all the information they need to anticipate and assess all project impacts.

One consequence of this emphasis on consultations as part of the decision-making process is that projects can become politicised, because the project sponsors are forced to secure the affected stakeholders' support for the project, which they do by disclosing information and then consulting with all stakeholders. If the affected people do not support the project, the project decision-makers cannot be confident that those people will act in the best long run interests of the project and that the project will be sufficiently sustainable to actually produce the expected benefits, or that it will have the predicted impacts. Consequently, the consultations become an arena of contest between those who support and those who oppose the project, in which each group seeks to use the consultations to advance their particular position.

Projects can also be politicised in another way. This occurs in cases where the MDB knows there are differences of opinions between the local stakeholders and the national government over the desirability of the project. In this case, the MDB will need to make a choice as to how to respond to these differences in opinion. This clearly places requires that the MDB take a position on a domestic political issue. While the basis for the MDB's decision is related to the feasibility and developmental implications of the project and to the borrower's ability to repay the loan, its need to incorporate the views of all the stakeholders into its decision-making process poses a challenge to its policy of respecting the sovereignty of the borrower member state and of complying with the political prohibition in its Articles of Agreement. $^{27}$

A third consequence of the emerging view is a blurring of the boundaries of the scope of each parties' responsibilities in a project. Under the consensus view, the scope of their responsibilities is relatively well-defined. Each actor's responsibilities are limited to those aspects of the project for which they have direct responsibility. This means that funding agencies like the MDBs are responsible for exercising due diligence before making a loan 
and meeting the obligations that they have assumed in their loan agreements with the borrowers. They will only be responsible for the way in which the projects are implemented and operated in the special case where they have gone beyond the normal role of project funders and become active participants in the design, construction and operation and maintenance of the project. ${ }^{28}$

The emerging view requires the MDBs, in their decision-making processes, to take into account the impact of the project and how this will evolve over the life cycle of the project. This means that, according to this view, they should be actively engaged, at least to the extent of being able to understand all the potential social and environmental impacts, in the design, construction and operation of the project. Since all aspects of the project are seen as interconnected, the sponsors and the MDBs cannot easily divide responsibility among themselves, making it more difficult to identify the limits of their responsibilities . In addition, the emerging perception requires project stakeholders to account for all the impacts of their activities over the entire life cycle of the project. This means that the MDB's responsibility could also extend over the entire life cycle of the project and for the period thereafter in which the project's impacts are still socially or environmentally significant. In fact, under this vision of development, any attempt to delineate the responsibilities of the project sponsors and the MDBs is a question of judgement and, therefore, requires debate and consultation.

The significance of the difference in perceptions of responsibility between the two views can be seen in the case of a dam project. Under the old consensus view of development, the scope of the MDBs' responsibility is limited to their direct contributions to the funding of the project itself. The duration of their responsibilities is limited to the time for disbursing their funds for the dam project and, at least in regard to monitoring the borrower, until the loan matures. On the other hand, the emerging view suggests that the MDBs must assume some responsibility for a priori assessment, and then monitoring the borrower's management of the dam's social, economic, cultural, political and environmental impacts on the whole river basin; its impact on all who depend on the river basin, and the impacts as they evolve over the period of the dam's construction, operation and decommissioning. Their responsibility may also continue during the period in which the environment and the affected people adapt to the decommissioning of the dam. 
This changing view of development project responsibilities has helped make the evolving relationship between governments and MDBs more complicated. Previously, the MDB could be reasonably confident that it was meeting its obligations if it deferred to the government on broad policy decisions and did an effective credit analysis and due diligence on the project. However, the changing scope of its responsibilities begins to call this into question. First, as the example of the dam project suggests, the project may have impacts outside the physical boundaries of the project, including outside the borders of the state in which the project is located, which the MDB must incorporate into its planning. This has implications for its relations with the member state that is sponsoring the project, the non-state actors who are affected by the project, and potentially other member states as well. In addition, it may not be sufficient for the MDB to defer to the sponsoring member state's view on these impacts. This is because there are international fora in which people adversely affected by projects can bring claims, and modern methods of communication may allow the affected people to call international attention to their plight and to the role that the MDB has played in it. In other words, the affected can create significant reputational risk for the MDBs merely by claiming, either in a legal forum or in the 'court' of public opinion that the MDB is responsible for their suffering because it did not, in conformity with applicable international standards, including the MDB's own policies, adequately assess the impacts of the proposed project before deciding to support it. ${ }^{29}$ Such claims can result in significant financial costs to the MDB and/or the member state sponsoring the project.

It is also noteworthy that the emerging view does not uphold the same degree of respect for the concept of sovereignty. Under the old consensus view, the sovereign has the final decision over the social, political, cultural, and environmental aspects of development projects. Under the emerging view, these 'externalities' have been 'internalised' and are now part of the responsibility of each of the actors in the development project. Thus a responsible MDB is expected to make its own decisions about these 'externalities' even if it places the MDB in conflict with the sovereign. The consequence of the emerging view, therefore, is that the sovereign is being reduced to only one among many actors in the development drama, and there is no clear justification for the MDB to give greater weight to the opinions of a sovereign than to those of other actors in the drama. In fact, the case for deferring to the sovereign's opinions is particularly subject to challenge when these opinions conflict with the expressed interests of those who will be most directly affected by the project. 


\section{The tensions generated by these differing views}

The fact that there is no longer a clear consensus on the relative responsibilities of governments, MDBs and non-state actors in regard to infrastructure projects is changing the dynamics in the field. There are new tensions in the relations between these three actors that could complicate efforts to develop the infrastructure so urgently needed in Southern Africa. The focus of this section is on the tensions that exist in each of these triangular relations.

The first relationship to be considered is that between governments and the MDBs. The relevant fault-line in this relationship is working out how to strike the appropriate balance between giving the governments the space to make and implement their own development plans, and allowing the MDBs to fulfil both the obligations undertaken in a project,, including those arising from the social and environmental aspects of their operations, and their mandates, by ensuring that they effectively utilise the resources that their member states have contributed. ${ }^{30}$ As indicated above, historically, the balance was struck by the MDB deferring to the government's view on the social, environmental, cultural and political aspects of the project but performing its own credit analysis and due diligence to ensure that the project was technically and financially feasible and that the borrower would be able to pay back the debts according to the agreed terms. This approach paid due regard to both the sovereignty of the borrowing state and to the interests of the MDB and all its member states. However, the growing international concern with the social and environmental consequences of these projects has pushed the MDBs to do more detailed social and environmental impact assessments of projects. This, in turn, has significantly increased the breadth and depth of MDB intervention into matters that were previously viewed as falling within the domestic affairs of the state and thus as the prerogative of the state. The MDBs, pursuant to these new responsibilities, have begun to open up new avenues for participation and accountability for non-state stakeholders, particularly adversely affected communities and groups, often at the expense of the sponsoring state. ${ }^{31}$ The net effect, at least from the perspective of the state, is not only to undermine the position of the state but also to slow down the development project planning and decision-making process.

One consequence of this development has been to reduce the attractiveness of the MDBs as a funding source for infrastructure projects. The reason is that that the additional work required in order to meet the higher and more complex standards required by the MDBs increases the up-front costs associated with the projects. In principle, these additional up-front costs 
should be recouped through greater efficiency and reduced social and environmental costs over the life of the project. The latter may be of minimal comfort to the government because in net present value terms the cost of the project actually increases relative to the benefits, which complicates the government's decision-making process. This situation can be particularly challenging for poorer countries that have limited financing options; for these countries, the participation of the MDB as a funder for a particular project can have a catalytic effect on other funders, assuring the latter that they can participate in funding the project on feasible terms. As a result, poorer countries are more vulnerable than richer developing countries to pressure from the MDBs to comply with their policies and practices and to being held accountable in cases of non-compliance.

Another consequence of the changed government-MDB relationship is that many emerging market governments are becoming frustrated with the lead time required for MDB funded projects and the up-front costs associated with preparing proposals for MDB financing. This is particularly relevant because, on average, large infrastructure projects, even under the best of conditions, tend to be substantially over budget and take more time to construct than anticipated. ${ }^{32}$ As a result, these governments are beginning to make greater use of ostensibly less demanding funding sources. This is one reason that so many African countries are looking with interest at developments in regard to the New Development Bank being created by the BRICS.

The second relationship that has experienced increased tension is that between state and nonstate actors around particular projects. One source of this tension is that groups and individuals that are adversely and directly affected by the project can now benefit from the more open information disclosure policies of the MDBs. These policies are designed to ensure, inter alia, that affected parties can gain access to relevant information on the project at a meaningful time, which inevitably means at an earlier moment in the project planning cycle. This may enhance their ability to protest against projects that they deem detrimental to their interests. Another source of tension is that this information can be used by either the affected people to encourage external non-state actors to take an interest in the project and to help promote their interests outside the country or by the external groups to inform local groups about the potential adverse impacts of the project. In both cases the non-state actors can use such mechanisms as the independent accountability mechanisms at the MDBs, and publicity and lobbying campaigns to oppose projects that they believe will harm their interests. ${ }^{33}$ They can also consider bringing their complaints to additional international fora 
such as human rights bodies or to grievance mechanisms in the home states of the companies and financial institutions working on the project. ${ }^{34}$ As indicated, these actions can have the effect of increasing the financial, political, economic and reputational cost of the project to the state, even if the non-state actor does not win its case in the relevant forum.

The third relationship that has become more intense and more conflicted is between non-state actors and the MDBs. This is occurring in several ways. As discussed above, the MDBs, because of their evolving environmental and social responsibilities, must now engage directly with those community groups that are adversely affected by the projects, and the organisations that represent them, to determine their views on the proposed project and how they will react to the project. One example of this is in the case of the World Bank and indigenous people groups. The World Bank now recognises that it must ensure that indigenous people are given the opportunity to give their free, prior informed consent for any project that may adversely affect them, even if the project is actively supported by the borrowing government. ${ }^{35}$ In addition, the MDBs must now also engage with international NGOs that are interested in their work and that have developed relations with the civil society groups that represent the communities that are affected by the projects. These groups have not always found these consultations to be satisfactory. Partly as a result of these experiences, some of these local and international groups are now also advocating for reforms in the operational policies and procedures of the World Bank, including increased transparency and accountability. Thus, the changing views of project responsibilities and practices are beginning to merge with the debates about reforms in the governance of the MDBs. This is likely to have a significant impact on the operational policymaking process in the MDBs. A good example is the almost two year consultation process that the World Bank has undertaken in revising its safeguard policies. ${ }^{36}$

\section{Implications for Southern Africa's relations with the MDBs}

As stated above, the governments of the Southern African countries will need to draw on the financing and advisory services offered by the MDBs in meeting the infrastructure needs of their citizens. This means that they will have little option but to comply with the MDBs operational policies and procedures regardless of how burdensome they might be in a particular case. ${ }^{37}$ Consequently, it would be advisable for them to actively engage with the efforts of some MDBs - for example the World Bank - to revise their social and environmental policies. 
There are three conclusions that follow from this observation. First, Southern African governments will need to pay careful attention to the operational policies and procedures of the MDBs in their planning and preparation of those infrastructure projects for which they would like to access MDB financing. Governments will, in addition, optimise their control over their own development process and mitigate the risks of surrendering undue control over this process to their external funders by ensuring that, when they approach project funders, they have prepared proposals that fully comply with their understanding and interpretation of the funders' operational policies and procedures. Since, at least in regard to social and environmental factors, MDB policies are considered international best practice, compliance with these policies is likely to ensure that the project proposals meet the requirements of all potential funders, including private commercial funders. Thus a project proposal that meets the requirements of the relevant MDBs should have the beneficial effect of increasing the bankability of the project and thus of the funding options available to the governments.

The second is that, in order to reduce their reliance on those MDBs that they find unduly demanding, Southern African governments need to work to diversify their range of potential funding options. As indicated, one way to do this is to ensure that all project proposals are well designed and prepared. Another is to identify alternative public and private funding sources. In this regard, the BRICS agreement to establish the New Development Bank is to be welcomed. It could potentially offer a new, and therefore additional, source of funding for infrastructure projects. It is important to note, however, that the New Development Bank has not yet established its own operational policies and procedures. Consequently, it is not yet known how it will deal with projects outside the BRICS countries, nor is it possible to know if it will have policies and procedures dealing with social and environmental factors that are significantly different from and less burdensome for borrowers than the currently existing MDBs.

The third conclusion is that Southern African governments need to be actively engaged, in a coordinated way, with the relevant MDBs, where appropriate, in regard to issues related to funding for specific infrastructure projects and in regard to broader policy and governance issues in the MDBs. A coordinated Southern African voice in dealing with the MDBs would be more powerful and persuasive than if the Southern African governments take a series of independent, even if relatively similar, positions in their interactions with the MDBs. This is particularly the case in regard to the largest MDB, the World Bank, because the Southern African countries have a small voice and vote in its affairs. This is significant because the 
World Bank Group tends to be the global leader in developing approaches to social and environmental issues that are later adopted by other MDBs and financial institutions. A coordinated position may result in other groups of countries, particularly emerging markets and developing countries, paying more attention to the Southern African countries' positions on these issues. This could also have a positive spillover in regard to Southern African states' participation in the governance reform discussion in these institutions.

Finally, a coordinated Southern African position could help encourage the numerous MDBs and other funders active in the region to work together and develop a mutually consistent and coherent set of operational policies and procedures in regard to projects that they are jointly funding. This would help reduce the transaction costs that Southern African governments must assume in dealing with multiple funding agencies, each of which usually has its own policies and procedures, in the context of specific infrastructure projects.

\section{Conclusion}

It will not be easy for Southern African countries to satisfy their infrastructure needs. They will need all the financial support that they can get in this regard. Consequently, they may have no choice other than to access MDB financing to help fund their infrastructure projects. This means that they will not be able to avoid the requirements of the MDBs' operational policies and practices relating to infrastructure projects, regardless of how demanding they may be and how slow they may make the approval processes for MDB loans.

This paper, in the hope that such information will help Southern African countries deal effectively with the challenges that they face in their relations with the MDBs, has sought to explain how and why the relationships between MDBs, states and non-state actors are changing. It has also sought to show that these changes are not specific to the MDBs and that they are influencing all funding sources. This suggests that Southern African governments will have no choice but to learn how to effectively manage the impact that the emerging view of development is having on infrastructure project financing, design, construction and operation. The paper also suggests that their efforts will be rewarded; with careful planning and coordination, the relationships between Southern African governments, the MDBs and non-state stakeholders in these projects can be managed effectively. As as result, the region would end up with more sustainable infrastructure that is better designed, constructed and operated, and with a more effective voice in the governance of MDBs. 
Note on contributor: Prof Daniel D Bradlow is the SARCHI (SOUTH AFRICAN

RESEARCH CHAIR INITIATIVE) Professor of International Development Law and

African Economic Relations at the University of Pretoria.

\begin{abstract}
${ }^{1}$ See, 'Southern Africa Regional Integration Strategy Paper: 2011-2015' African Development Bank (2011) pp 14-17, available at: http://www.afdb.org/fileadmin/uploads/afdb/Documents/Project-and-Operations/20112015\%20-\%20Southern\%20Africa\%20-\%20Regional\%20Integration\%20Strategy\%20Paper.pdf (visited 20

March 2015)

${ }^{2}$ For the purposes of this article there is no meaningful distinction between banks like the World Bank and regional development banks. Both groups of banks tend to have similar, although not identical, operational policies and procedures dealing with the social and environmental aspects of their projects. While the differences between these policies can be interesting, they cannot be explored without some detailed analysis of the specific operating policies of these different banks. Such a textual analysis is outside the scope of this paper, and is sufficiently complex that it would justify its own paper.

${ }^{3}$ See, for example, 'A Stronger, Connected, Solutions World Bank Group: An Overview of the World Bank Group Strategy', pp5-8 available at:

https://openknowledge.worldbank.org/bitstream/handle/10986/16093/32813 ebook. pdf?sequence=5 (accessed 18/03/2015) Also see: 'What We Do' available at http://www.worldbank.org/en/about/what-we-do ${ }^{4}$ The current governance arrangements in the World Bank Group pose significant problems for the operations of the World Bank in regard to its funding of infrastructure projects. However a full exploration of this issue is beyond the scope of this paper. The problem also exists, albeit to a lesser extent in the regional development banks like the African Development Bank. There is an extensive literature on this topic, see, for example, D.Bradlow, 'The Reform of the Governance of the IFIs: A Critical Assessment' 'International Financial Institutions and Global Legal Governance' edited by H. Cisse, D. Bradlow and B. Kingsbury (The World Bank 2012); International Financial Institutions and International Law', D. Bradlow and D. Hunter (eds) (Kluwer Press, 2010)

${ }^{5}$ For more information on the accountability of the MDBs, see D. BRADLOW AND A. NAUDE FOURIE, 'Independent Accountability Mechanisms at International and Regional Development Banks' (in 'Handbook of Innovations in Transnational Governance', D. Held and T. Hale (eds) (2011); D. BRADLOW AND M. CHAPMAN, 'Public Participation and the Private Sector: The Role of the Multilateral Development Banks and the Evolving Legal Standards' 4 Erasmus Law Review2 (2011) available at: $\underline{\text { http://papers.ssrn.com/sol3/papers.cfm?abstract id=1971695 }}$
\end{abstract}

${ }^{6}$ See, for example, A Naude Fourie, The World Bank Inspection Panel Casebook (2014); 'World Bank Group's Safeguards and Sustainability Policies Were Put in Place to Prevent or Mitigate Adverse Impacts of Its Projects on People and the Environment.'

http://siteresources.worldbank.org/EXTSAFANDSUS/Resources/exec summary.pdf (accessed 19/03/2015). Also

${ }^{7}$ In reality, it is unlikely that the electorate will base its decision on whether or not to support the current government on its management of one particular project. Voters are more likely to base their decision on whom to vote for on the entirety of the government's record and their policy proposals for the period of the next government.

${ }^{8}$ MDBs require that the projects they support produce an economic benefit at a feasible financial cost because they have a developmental mandate. See IRBD Articles of Agreement Article I. Also see generally ES Mason \& RE Asher The World Bank since Bretton Woods (1973).

$9 \mathrm{~J}$ Klabbers, 'An Introduction to International Institutional Law' (2009). Also see, 'Convention of the Privileges and Immunities of Specialised Agencies Convention', entered into force on 2 December 1948. This is applicable to the International Bank for Reconciliation and Development and the International Monetary Fund, which are UN specialised agencies;

${ }^{10}$ There are many examples of such campaigns--See for example Narmada Dam project. B Morse \& TR Berger Sardar Sarovar Report of the Independent Review (1992)349-358 'These Bank policies reflect the global 
adoption of new concepts of human rights. They constitute a recognition that large-scale projects, especially in rural, forested, and frontier areas, may displace people just as do war and natural calamities'

${ }^{11}$ See, generally, M. Sornarajah The International Law on Foreign Investment (2004)

${ }^{12}$ This is expressed in the political prohibition that is found in the articles of agreement of most MDBs. See, for example, Art IV (10) of IBRD Articles of Agreement and Art 38 (2) of African Development Bank Articles of Agreement.

13 In this regard it is interesting to note that a recent study shows that, even under the best of circumstances, most projects are 'over budget, over time, over and over again'. In the case of large dams, projects are on average about $94 \%$ over budget. See B Flyvbjerg, 'Survival of the Un-fittest: Why the Worst infrastructure Gets Built - and What We Can Do About It', Oxford Review of Economic Policy vol. 25 344-367 (2014).

${ }^{14}$ See, generally, D Hunter et al, International Environmental Law and Policy (2007).

${ }^{15}$ See, generally, JP Bohoslavsky \& JL Černič Making Sovereign Financing and Human Rights Work (2014)

${ }^{16}$ DD Bradlow 'Private Complainants and International Organizations: A Comparative Study of the Independent Inspection Mechanisms in International Financial Institutions' Georgetown Journal of International Law (2005)

${ }^{17}$ For more information on Commission, see: http://www.achpr.org/ The case law of the Commission is available at: http://www.chr.up.ac.za/index.php/documents/african-human-rights-case-law-database.html ${ }^{18}$ See, generally, DD Bradlow \& D Hunter INTERNATIONAL FINANCIAL INSTITUTIONS AND INTERNATIONAL LAW (2010)

${ }^{19}$ http://www.ifc.org/wps/wcm/connect/topics ext content/ifc external corporate site/ifc+sustainability/ou r+approach/risk+management/ifcsustainabilityframework_2012\#SustainabilityPolicy (accessed 19/03/2015)

${ }^{20}$ http://www.equator-principles.com/index.php/ep3 (accessed 19/03/2015)

${ }^{21}$ http://www.ohchr.org/Documents/Publications/GuidingPrinciplesBusinessHR_EN.pdf

${ }^{22}$ https://consultations.worldbank.org/consultation/review-and-update-world-bank-safeguardpolicies (accessed 19/03/2015)

${ }^{23}$ UN General Assembly Resolution, Declaration to the Right to Development A/RES/41/128, available at: http://www.un.org/documents/ga/res/41/a41r128.htm, (accessed 19/03/2015)

${ }^{24}$ Each MDB has a set of operational policies that, inter alia, deal with how they should manage the environmental and social implications of their operations. The following are citations to the World Bank and the African Development Bank's operational policies on these issues: Piloting the Use of Borrower Systems to Address Environmental and Social Safeguard Issues in Bank-Supported Projects:

http://web.worldbank.org/WBSITE/EXTERNAL/PROJECTS/EXTPOLICIES/EXTOPMANUAL/0,,contentMDK:20403 230 menuPK:64701637 pagePK:64709096 piPK:64709108 theSitePK:502184 isCURL:Y,00.html (accessed 19/03/2015); African Development Bank Group's Policy on the Environment, http://www.afdb.org/fileadmin/uploads/afdb/Documents/Policy-Documents/10000027-EN-BANK-GROUPPOLICY-ON-THE-ENVIRONMENT.PDF (accessed 19/02/2015).

${ }^{25}$ See, for example, The World Bank Policy on Disclosure of Information, June 2002, http://siteresources.worldbank.org/OPSMANUAL/Resources/DisclosurePolicy.pdf, (accessed 19/03/2015); Disclosure and Access to Information Policy, http://www.afdb.org/fileadmin/uploads/afdb/Documents/PolicyDocuments/Bank Group Policy on Disclosure and Acess to Infomation.pdf, (accessed 19/03/2015)

${ }^{26}$ See, for example, the World Bank's operational policy on indigenous people, available at: http://web.worldbank.org/WBSITE/EXTERNAL/PROJECTS/EXTPOLICIES/EXTOPMANUAL/0,,contentMDK:20553 653 menuPK:4564185 pagePK:64709096 piPK:64709108 theSitePK:502184,00.html (accessed 19/05/2015); and the African Development Bank's gender policy, available at: http://www.afdb.org/fileadmin/uploads/afdb/Documents/Policy-Documents/10000003-EN-THE-GENDERPOLICY.PDF (accessed 19/05/2015)

27 'See, for example, Article IV (10) IBRD Articles of Agreement.

${ }^{28}$ In some circumstances a lender may incur liability for the way in which its debtor manages the business funded by the loan. This is particularly likely where it can be shown that the lender has excised substantial influence over the debtors business. See, generally, H Parker, Principles of Lender Liability (2012)

${ }^{29}$ This is the basis of claims that are brought to the independent accountability mechanisms of the MDBs. See Bradlow, supra, note 16 
${ }^{30}$ The MDBs are all subjects of international law. Consequently, their responsibilities include compliance both with the applicable customary international legal principles and treaties and the obligations spelled out in their founding treaties. See DD Bradlow \& D Hunter, supra, n18 above

31 This is one of the effects of the MDBs information disclosure policies and consultation policies. It is also the purpose of the independent accountability mechanisms established at the MDBs. See DD Bradlow, supra, n18 and A. Naude Fourie, The World Bank Inspection Panel and Quasi-Judicial Oversight: In Search of the 'Judicial Spirit' in Public International Law. Both the World Bank Group and the African Development Bank have operational policies that seek to encourage civil society organisations to get involved in their projects. See The World Bank Group, 'The World Bank and Civil Society Engagement' available at: http://web.worldbank.org/WBSITE/EXTERNAL/TOPICS/CSO/0,,contentMDK:20092185 menuPK:220422 page PK:220503 piPK:220476 theSitePK:228717,00.html, African Development Bank, The Framework for Enhanced Engagement with CSOs, available at: http://www.afdb.org/en/topics-and-sectors/topics/civilsociety/the-framework-for-enhanced-engagement-with-csos/

${ }^{32}$ See B Flyvbjerg, supra note 11

${ }^{33}$ See, generally, A Naude Fourie, The World Bank Inspection Panel Casebook (2014).

${ }^{34}$ Some projects that have been brought to such bodies for resolution include: Bello Monte Dam in Brazil see http://www.economist.com/news/americas/21577073-having-spent-heavily-make-worlds-third-biggesthydroelectric-project-greener-brazil , the Chad-Cameroon pipeline see F Clausen \& A Attaran 'The ChadCameroon Pipeline Project--Assessing the World Bank's Failed Experiment to Direct Oil Revenues towards the Poor' Law and Development Review Volume 4, Issue 1, Pages 32-65; the Baku-Tblisi- Ceyhan pipeline see: http://belfercenter.ksg.harvard.edu/publication/12795/from pipe dream to pipeline.html)

${ }^{35}$ See, for example, the World Bank's indigenous people policy available at: , IFC sustainability framework. http://web.worldbank.org/WBSITE/EXTERNAL/PROJECTS/EXTPOLICIES/EXTOPMANUAL/0, contentMDK:20553 653 menuPK:4564185 pagePK:64709096 piPK:64709108 theSitePK:502184,00.html and the International Finance Corporation's Sustainability Framework, available at: http://www.ifc.org/wps/wcm/connect/7540778049a792dcb87efaa8c6a8312a/SP English_2012.pdf?MOD=AJ PERES. It should be noted that the Equator Principles, see, supra note 18, which are the principles that the private banks, apply to their project lending are based on the IFC's principles and closely track their requirements.

${ }^{3636}$ See: https://consultations.worldbank.org/consultation/review-and-update-world-banksafeguard-policies (accessed 19/03/2015)

${ }^{37}$ This statement should not be interpreted to mean that there is no room for negotiation with the MDBs about how to apply their operational policies and procedures to particular projects. However, in general, these negotiations will be limited to questions of interpretation of the applicable policies and procedures. There is limited scope for complete exemptions from the MDB's rules. 